\title{
Modern Money Theory: a criticism from the periphery
}

Rodrigo Vergnhanini ${ }^{1}$

Bruno De Conti ${ }^{2}$

\begin{abstract}
This paper presents the recent debate on modern money theory (MMT) and contributes to a critical view on its application to peripheral countries. MMT has been centered on both demystifying postulates of the 'New Macroeconomic Consensus' and offering an alternative theory to reach full employment with price stability. However, it has been criticized for assuming that constraints on domestic policies are generally self-imposed, not arising from international markets. Using the "international currency hierarchy" approach, this paper argues that peripheral countries, in the context of financial globalization, are not fully sovereign in determining its own macroeconomic policy. Our main argument is that currencies issued by peripheral countries do not fulfill money classical functions at the international level. Being hence illiquid at the international scenario, these peripheral currencies (and assets) are demanded by the international investors only in the quest for high returns; moreover, this demand depends on the "international liquidity preference" and the markets' confidence in this country. Consequently, interest rates in peripheral countries tend to be higher and volatile. Additionally, the exchange rate is potentially under the pressure of this capital flows movements. Finally, monetary, fiscal and exchange policies in peripheral countries have constrains that are not considered by MMT.
\end{abstract}

Keywords: modern money theory, currency hierarchy, functional finance, policy constraints, peripheral countries.

JEL Classification: E40, E63, F40.

\footnotetext{
1 PhD candidate at the Institute of Economics, University of Campinas, Brazil. E-mail address: verg.rodrigo@gmail.com

2 Professor at the Institute of Economics, University of Campinas, Brazil. E-mail address: brunodeconti@eco.unicamp.br
} 


\section{Introduction}

The Modern Money Theory (MMT) approach has gained increasing visibility for predicting the crisis of the European Monetary Union (EMU). Already in the 1990s, MMT claimed that the EMU institutional design would lead to growth problems due to the absence of fiscal branch. 'It will be as if each EMU member country were to attempt to operate fiscal policy in a foreign country; deficit spending will require borrowing in that foreign currency according to the dictates of private markets' (Wray 1998, p. 92). Although there is much disagreement regarding the causes of EMU stagnation (even among heterodox economists), MMT took advantage of its acknowledged economic forecasts to claim the victory of their theoretical assumptions over mainstream economics (see Wray 2012).

On the one hand, MMT raises important questions to demystify some elements of the so-called "New Macroeconomic Consensus" (NMC) ${ }^{3}$. For instance, it refutes the necessity of causing recession and unemployment as the only efficient path in order to restore balanced growth.

On the other hand, it has been criticized for assuming that countries are, in almost every case, free from international markets to unrestrictedly expand government deficit and set domestic macroeconomic policies so as to provide full employment. Any fear of deviating from markets' rules would be based on irrational fear and on misunderstandings on how economy and public budget actually functions. Due to these claims, MMT has attracted criticism from both the orthodox and the heterodox economics.

The purpose of this article is to develop a heterodox critique against MMT, from the perspective of the "international currency hierarchy" framework. In essence, it argues that countries do face external constraints over domestic policies and that the disciplinary power of international markets is greatly asymmetric, being more severe in those countries that issue the so-called peripheral currencies.

The article is divided in four sections, in addition to this introduction. Section two introduces MMT's theoretical underpinnings as well as its policy proposals, based on Wray's seminal work Understanding modern money (1998) and some recent articles. The third chapter presents some general appraisals from heterodox economists; Thomas Palley's works were greatly considered, since they provide a wide compilation of MMT's problems, from both theoretical and practical standpoints. Section four adds a periphery perspective in order to contradict MMTs main claim of 'macroeconomic sovereignty' as a generally applicable rule; this section is aligned with the research scope on 'international currency hierarchy', that argue that the International Monetary System asymmetries are quite important for the understanding of economic dynamism and policy options in any country. Finally, some conclusive remarks are raised.

\section{Modern Money Theory: foundations and general criticism}

The MMT seeks to demystify some common views regarding the functioning of the economy and builds a theoretical framework to support its bold policy proposals. The present section explores the MMT view on: i) the nature of government deficits; ii) the supply of

\footnotetext{
${ }^{3}$ For details about the NMC, see Arestis and Sawyer (2008).
} 
money; iii) the role of external sector; and iv) policy propositions. The main reference is Wray (1998), but it also includes some recent developments of this theoretical approach.

According to the conventional view, government spending mainly relies on tax revenues. Any deficit budget should be financed either through the issuing of non-interest bearing debt by the Treasury (currency) or through the selling of interest-earning bonds. The first alternative is commonly believed to cause inflation, since it directly expands the money supply. Government borrowing, on the other hand, increases the demand for loanable funds, possibly driving up interest rates and, at least partially, crowding out private borrowing. Over the long run, this could lead to supply bottlenecks and cost-push inflation.

Most economists of different persuasion believe that government deficits may even be desirable in specific situations. However, their persistent shape should be avoided because it could lead to some deficit-to-GDP ratio in which market loses confidence in governments' ability to retire its debt. In this sense, government deficit is supposed to rely on domestic public expectations and its will to take up the debt. Eventually, the government would have to impose austerity on its population with the aim of conquering (or reconquering) markets' confidence in order to sell bonds internationally.

The MMT approach is based on Lerner's concept of 'functional finance'. It states that rather than tax revenues or bond sales, government spending is financed through fiat money ${ }^{4}$. The reasoning is considered as follows.

Firstly, the government issues fiat money and spends it by hiring services and buying products from the public. The state money is widely accepted because it is the only unit of account that officially meets tax liabilities. We see therefore the crucial influence of the chartalist view proposed by Knapp (1924), according to which non-metallic money is accepted due to the ability of the state to impose and collect taxes in this currency. That is why some authors refer to the MMT as the "neo-chartalists" (e.g. Lavoie 2013, 2014).

From this perspective, taxes serve simply as a reserve clearing drain that is flowed back to the government funds. Because taxes cannot be paid until state money is injected in the economy, persistent government deficits derive from the normal functioning of the economy and surpluses, on the opposite side, unleash strong deflationary forces.

As a result, according to MMT, government deficit spending is never subject to market discipline as long as the bonds are issued in the domestic currency. Furthermore, 'most of the pressures that governments currently believe that arise from international markets are actually self-imposed constraints coming from a misunderstanding of the nature of government deficits' (Wray, 1998, p. 75). Debt-limit rules, balanced budget requirements as well as the setting of a sovereign currency system based on the conversion to gold or to foreign currency are constraints that should be understood as 'necessarily politically imposed'

\footnotetext{
${ }^{4}$ Fiat Money is the one that has no inherent value neither any "real backing". Its value is therefore based only on trust. For details, see Knapp (1924) and Goodhart (1989).

${ }^{5}$ According to Lavoie (2013, p.2), "[b]esides the obvious authors who have inspired modern chartalists, Smith, Knapp and Keynes, it may be said that the originators of modern monetary theory are Warren Mosler, Hyman Minsky, Abba Lerner and Wynne Godley, as their writings are often invoked by neochartalists".
} 
(Wray, 2014b, p. 29).

This reasoning rests upon the idea that the government is sovereign to issue any amount of state money and is completely capable of maintaining its value. According to the famous sentence proposed by Lerner (1943, p. 313), "money is a creature of the state". In addition - as discussed above -, its acceptability could never be questioned because it is enforced by the payment of tax liabilities.

Another important theoretical underpinning of MMT regards the supply of money. Some economists have not abandoned the traditional monetarist belief that the central banks set the amount of money and that this determines the rate of inflation ${ }^{6}$. According to this view, the monetary authority provides reserves to the banking system and, through a 'stable' money multiplier, it expands the money base. In the textbooks, this has been called the 'verticalist' approach (money supply being completely inelastic to interest rates).

However, according to MMT - in line with Keynesianism -, the central bank has never controlled the quantity of money or the amount of reserves. 'In the real world banks make loans not mattering the reserve positions, afterwards borrowing reserves to meet requirements' (Wray 1998, p. 107).

The decision to lend money depends on the price of reserves and the expected returns. In other words, the bank lends money if it assumes that this operation is profitable, regardless of the quantity of reserves. It plays an active role in determining the composition of its assets and liabilities. Hence, the causation is the reverse of what is commonly stated: firstly, the provision of loans meets the demand for finance; secondly, the bank buys reserves from the central bank in order to meet the legal requirements. In this scheme, the central bank plays a quite passive role, providing or draining the amount of reserves determined by the banking operation.

MMT incorporates the 'horizontalist' approach, which means that: i) the central bank determines the short-term interest rate directly (and the short-term retail lending indirectly, as the wholesale rate is marked up); and ii) the supply of money is endogenous to finance demand.

The assumptions on money supply, government finance and value of the currency have important implications on the role of monetary and fiscal policies.

The orthodox view assumes that the monetary policy has discretionary control over the reserves and the quantity of money. The MMT claims that 'the orthodox view fundamentally confuses fiscal policy with monetary policy; fiscal policy has more to do with the quantity of money and with the value of it while monetary policy simply determines overnight interest rates' (Wray, 1998, p. 98). Monetary policy is defensive and dependent on the Treasury operations. It includes those Treasury and central bank operations that drain reserves or set the overnight interest rate target. Bond sales are destined to substitute non-interest earning government fiat money for interest-earning government liabilities (and constitute an interest rate maintenance account). Fiscal policy, on the other hand, is intended to determine the quantity of state money available and, through taxation, maintain the value of the

\footnotetext{
${ }^{6}$ For details, see Friedman (1953).
} 
currency. As mentioned above, the goal of the fiscal policy is to operate based on the functioning of the economy and not on what the traditional doctrine called 'sound finance'. The principle of functional finance, advocated by Abba Lerner (1943, p. 39), states that:

“(...) the first financial responsibility of the government (...) is to keep the total rate of spending in the country on goods and services neither greater nor less than that rate which at the current prices would buy all the goods that is possible to produce".

Spending and taxes should therefore be balanced to accommodate full employment. However, the operation of functional finance is not enough to guarantee that condition. How could the government generate full employment and at the same time keep price stability?

The MMT recommends the government acting as an employer of last resort (ELR), providing jobs at a basic public sector wage (BPSW). Any person who is able and willing to work would be provided with a job in the ELR program. The BPSW would be set by the government at a level that is lower than the minimum wage in the private market. As the economy grows, some workers would be transferred from the ELR program to the private market, receiving better salaries. On the other hand, in cycle downturn ELR could accommodate workers dismissed by private firms. This way, the buffer stock program would stabilize aggregate income and aggregate demand, diminishing regressive effects of recession (Mitchell and Wray, 2005).

At the same time, since it constitutes an important element in the production cost of every economic activity, the unskilled labor is supposed to be the best commodity for the buffer stock program. The stabilization of the ELR wage would serve as reference to other wages, costs and prices, thus contributing to overall price stability (see Mitchell, 1998). The ELR would therefore allow the government deficit to vary countercyclically, filling the demand gap and avoiding deflationary pressures.

Summing up, the MMT claims that the government has autonomy to increase deficit spending by issuing money or selling bonds at any amount needed (as long as the bonds are issued in the domestic currency). Because it could never default the payment of a debt that is denominated in its own currency, the market would not doubt its payment capacity. Since the government is free of any market constraints in its policy-making, it should implement a finetuning between monetary and fiscal policies in order to reach and maintain full employment with price stability.

Wray $(1998,2012)$ and Tcherneva (2006) assume that the external sector does not constraint autonomous domestic policies as long as: i) the exchange regime is free from any pegging rules; ii) the government is not indebted in a foreign currency. In this case, if the exchange rate is free to float, then it would adjust to domestic policies without major consequences ${ }^{7}$.

The MMT recognizes that if the country is forced to international indebtedness because it is obliged to issue debt in a foreign currency or because it needs goods or services

\footnotetext{
${ }^{7}$ Lavoie (2014, p. 343) states that this argument is "relatively uncontroversial". Unlike, this paper will try to demonstrate that it is quite controversial, notably for peripheral countries.
} 
that are not available in exchange for the domestic currency, then it would be subjected to constraints of international markets (Wray, 2014a).

\begin{abstract}
"Sometimes governments believe that the 'market' forces them to issue foreign-currencydenominated bonds. There is only one case in which this would be true - when the government wishes to purchase goods and services that are not for sale in terms of the domestic fiat money. (...) [in this case] it will have to obtain additional foreign currency in the future to service the debt. In some situations, markets might fear that a government will not be able to do this - which could lead to default - causing a rational run out of these bonds. As a result, the government may be forced to impose austerity on its population to maintain a trade surplus to obtain the needed foreign currency" (Wray 1998, p. 88).
\end{abstract}

However, this condition is considered by MMT to be punctual, not applying to the general case:

\begin{abstract}
"In this one case, the austerity can be at least partially blamed on 'market discipline'. However, it must be recognized that this is only because the government desired goods and services that were not for sale in the domestic currency. In all other cases, the government is not subject to 'market discipline', and any austerity and hardship is self-inflicted" (Wray, 1998, p. 88)
\end{abstract}

\title{
3. General criticisms
}

One may therefore notice that the MMT raises important debates. On the one hand, it contradicts the conventional theory, notably on the assumption of the governments' necessity to always and accurately obey to the so-called "market discipline". On the other hand, it raises polemic arguments even for non-orthodox authors. That is why several criticisms are being placed on the assumptions of MMT, stimulating rich debates. In this section, some of the most important heterodox appraisals are considered.

The first disagreement is related to the origin of money. As discussed in the previous section, MMT states that the value of money derives exclusively from public demand through the imposition of taxes. Rochon and Vernengo (2003) and Palley (2015a, 2015b) criticize this simplification. Although they agree that state money is Chartal, they assert that this must not be seen as the core of the concept; money in the broader sense should be rather defined according to the fulfilment of its three functions: store of value, exchange means and unit of account (in accordance with Keynes' writings) ${ }^{8}$.

Lavoie $(2011)^{9}$, Palley (2015a, 2015b) and Cesaratto (2016) also question the 'consolidation' assumption between the monetary and the fiscal authorities, proposed by the MMT. On that matter, Lavoie (2013) states that insisting in this "fictitious" assumption creates room for misunderstanding. In his opinion, claiming, for instance, that taxes and securities do not finance the expenditures of central governments is counter-productive because it has no adherence to the reality - even in the USA.

From a theoretical perspective, Palley (2013) questions the lack of a rigorous

\footnotetext{
${ }^{8}$ Four functions if we consider the finance function (Keynes, 1930).

${ }^{9}$ In spite of some criticisms, Lavoie $(2013,2014)$ agrees with many of the statements of the MMT.
} 
explanation for the functioning of both inflation and interest rates. According to Palley, MMT implicitly assumes 'L-shaped' inflation curve and ignores the developments attained by the Phillips curve (less unemployment tends to lead to inflationary pressures). In addition, it also places no role to expectations in the process of price formation. Palley believes this configures a regression in the understanding of the inflationary phenomenon.

It is worth noting that Keynes (1936, chapter 21), whose work served as important inspiration for the MMT approach, argued that inflationary pressures may arise as a consequence of economic growth even when the economy is below the level of full employment ${ }^{10}$ - thus, denying the validity of an "L-shaped" inflation curve.

Furthermore, Palley (2013) argues that a zero natural interest rate - as MMT implicitly assumes - would lead to inflation and asset instability (in a Minskyan perspective). Monetary policy, supposed to operate exclusively in a defensive manner in response to fiscal policy measures, loses its purpose in fighting instability of domestic financial sectors. Tymoigne and Wray $(2014$, p. 31) replied to that criticism by arguing that financial regulation should be enough to counterbalance low interest rate and promote stability.

When open economies are regarded, MMT has recently emphasized the role of flexible exchange rate as a stabilizing device in countries that need to obtain foreign currency.

According to the critics, differently from what MMT advocates, exchange rates should not be free to float. Palley (2015b) reminds that a major reason why flexible exchange rates do not insulate economies comes from structuralist macroeconomics literature, principally associated with Latin America. In this perspective, exchange rate depreciation triggered by money financed deficits can cause significant disruptive imported-inflation effects in both developing and open-developed economies. Krugman and Taylor (1978) argued long ago that exchange rate depreciation can also be contractionary, due to distributional effects on aggregate spending. Although not referring to MMT, Flassbeck (2001) and, more recently, Rey (2015) also proposed that a free exchange rate regime in emerging countries do not insulate their economies - not allowing therefore an autonomous economic policy.

Moreover, Palley argues that the covered interest parity (CIP) is incompatible with MMT. Its recommendation of setting domestic interest rate at zero would require, as to avoid capital reflux, a process of continuous domestic currency appreciation, which, in term, would lead to financial instability and real economic disruption (Palley 2015b, p. 55).

Cesaratto (2012a, 2012b, 2012c) agrees that there are important open economy considerations neglected by MMT. For instance, the great majority of 'real-world' economies

\footnotetext{
${ }^{10}$ Keynes presents five motives for that matter: "i) effective demand will not change in exact proportion to the quantity of money; ii) since resources are not homogeneous, there will be diminishing, and not constant, returns as employment gradually increases; iii) since resources are not interchangeable, some commodities will reach a condition of inelastic supply whilst there are still unemployed resources available for the production of other commodities; iv) the wage-unit will tend to rise, before full employment has been reached; $v$ ) the remunerations of the factors entering into marginal cost will not all change in the same proportion" (Keynes, 1936 [1964], chapter 21, p. 254).
} 
need to obtain goods and services that are not for sale in the domestic currency. This means that the necessity of obtaining foreign currency and maintaining the power parity of its national currency in terms of foreign one is rather a general rule than an exception. Therefore, in order to overcome the foreign constraint, governments may have either to adopt fixed exchange rate regimes and attract foreign finance, or to limit their growth ${ }^{11}$ rate. Therefore, austerity is not always self-imposed, as argued by MMT, but most of economies are, in fact, subjected to some kind of 'market discipline'.

According to Cesaratto, MMT focuses much on the 'internal aspect' of full money sovereignty. However, full sovereignty depends also on the capacity of issuing an internationally accepted currency. Cesaratto highlights that only the currencies of mercantilists countries - that is, those with persistent current account surpluses - and the United States of America may have unlimited acceptance. Non-mercantilist countries do need to implement exchange rate management in order to obtain external equilibrium.

In response to these criticisms concerning the functioning of open economies, some MMT exponents (e.g. Tymoigne and Wray, 2014) have advocated exchange rate pegging. This acknowledgment however undermines MMT's main claim about sovereign money freeing governments from standard market disciplines and financial constraints (Palley 2015b, p. 55). Pegging limits the freedom of monetary policy, requires foreign exchange reserves and is also subjected to speculative attacks, which further constrain policy.

\section{Critique from the periphery}

This final section intends to show how some monetary specificities of peripheral countries tend to determine even further restrictions on macroeconomic autonomy. From a more general perspective, there may be other specificities in the periphery, apart from the international monetary aspect, that cause diminished macroeconomic sovereignty. For instance, domestic supply bottlenecks may become a difficulty for the country to autonomously increase its aggregate demand without causing deficits in external trade ${ }^{12}$. However, the present section intends to focus exclusively on the external constraints placed by the status of peripheral currencies at the international monetary system (IMS).

First of all, it is important to notice that only a few national currencies are able to satisfy the three basic functions of money also in the international scenario ${ }^{13}$. According to De Conti et al. (2013, pp. 4-5), this ability is determined by international political economy conditions, such as the issuer's economic dimension and integration with the world economy,

\footnotetext{
${ }^{11}$ On this matter, see the contributions of Thirlwall (1979), as well as the further developments of the literature on external constrained growth models.

${ }^{12}$ For details, see the works from the ECLAC (e.g. Bielschowsky, 2000).

${ }^{13}$ A great reference for the studies concerning the different abilities of the national currencies to fulfil their classical functions at the national and the international level, see Cohen (1998). Eichengreen et al. (2005) discusses the inability of many countries to issue external debt in their own national currencies (the authors name it "original sin"); although quite interesting, this proposal does not consider all implications arising for a country from the fact that it issues a currency that does not fulfil internationally any of the classical functions of money.
} 
its geopolitical power and its will to internationalize its currency ${ }^{14}$.

The international monetary system is therefore configured by domestic currencies with different abilities to fulfil their functions at the international level. The US dollar represents currently the system's key-currency. The second most important currency regarding the international use is the euro. At a third level, we find the Japanese yen, the Sterling pound, the Swiss franc, the Canadian dollar and the Australian dollar ${ }^{15}$. All of them may be named 'central currencies', since they are also used at the international level. On the other hand, there are the national currencies that cannot fulfill money's classical functions in the international scenario: the 'peripheral currencies'. Since they are not money at the international level, these currencies are demanded worldwide only as financial assets.

In order to understand the quality (or the characteristics) of the demand for these currencies, it is hence useful to analyze the theory of portfolio choice. According to Keynes, monetary economies are characterized by fundamental uncertainty and, in this context, the liquidity preference figures as a good thermometer of agents' expectations and confidence. According to Keynes' portfolio choice model (Keynes, 1936, chapter 17; Keynes, 1930), an asset yields, altogether with quasi-rent (q), maintenance cost (c) and capital gains (a), a liquidity premium $(\mathrm{I})^{16}$. This justifies why agents allocate part of their wealth in liquid applications - including money -, even if they provide lower - or none - monetary returns. The attribute of liquidity depends on the asset capability to be converted into means of payments with little monetary and temporal costs. Domestically, state money is normally the most important means of payments ${ }^{17}$, so it is the liquid asset par excellence. All other assets must therefore offer a monetary return that is enough to compensate their relative illiquidity against money. In Keynes' words, bonds yield interest rates in order to offer a premium for its illiquidity.

Transferring this reasoning to the international level, it is important to notice that only a few currencies are used as means of payments ${ }^{18}$. Therefore, only these currencies are the liquid assets par excellence' at the international arena. All other currencies, that we name 'peripheral currencies', are not liquid at the international level, even if they are domestically

\footnotetext{
${ }^{14}$ The determinants of the international usage of a currency are far from consensual. Resende and Amado (2007) and Resende (2005) claim for instance that the current account performance is the main cause of a country's currency position in the International Monetary System.

${ }^{15}$ Some authors may find it better to include also the New Zealand dollar and some other currencies. Since this paper focuses on the peripheral currencies, these controversies concerning the list of the "central currencies" do not cause any problem for the arguments. It is also important to notice that the Chinese renmimbi is quickly increasing its usage at the international level; this issue goes however beyond the scope of this paper (for details, see for instance Guttmann, 2016).

${ }^{16}$ Andrade and Prates (2013) propose an interesting analysis of the exchange rate dynamics that uses this Keynes (1936 [1964]) chapter 17's equation.

${ }^{17}$ In some countries, international currencies are used domestically as a mean of payments too, but it configures an exception. For an analysis of the currencies that do not fulfil money classical functions even in the domestic level, see Cohen (1998).

${ }^{18}$ There are no precise data concerning the currencies used for the international trade, but Guttmann and Plihon (2011) indicate that the US dollar's share is between 40 and 45\% and the euro's share is within the range of 15 and $20 \%$ of the total. De Conti and Prates (2016) show with data from the SWIFT Watch that for the Customer initiated and institutional payments, US dollar (43\%), Euro (30\%) and Sterling pound (9\%) are responsible for $82 \%$ of the transactions (data for Nov. 2015).
} 
the most liquid assets. Hence, these peripheral currencies (and the assets denominated in these currencies) have to pay a premium for this 'international illiquidity' (De Conti, 2011). The direct consequence is that bonds denominated in peripheral currencies have a priori higher interest rates, since these rates have to satisfy global investors' exigency to earn a premium for the international illiquidity of these assets.

For that reason, the uncovered interest rate parity (UIP) theory is not sufficient to explain the determination of the interest rate level. It states that domestic interest rate should equal international interest rate plus the country risk premium and the expected exchange rate variation. However, due to the above-mentioned monetary asymmetry, peripheral countries must offer an additional premium in order to offset the currency international illiquidity ${ }^{19}$.

The implicit return attributed to liquidity depends on agents' liquidity preference. Then, this dimension is not objective, but it is based on conventions, being therefore susceptible to a great volatility. Consequently, peripheral countries are not able to freely determine the short-term interest rate. First of all, the assets denominated in peripheral currencies (including public bonds) have to pay a premium for their international illiquidity. Secondly, since the 'international liquidity preference' (De Conti 2011, Guttmann 2016) may change suddenly and intensively, peripheral currencies interest rate must reflect it, tending to be highly volatile ${ }^{20}$.

In the context of financial globalization, national currencies are also financial assets associated to the trade-off returns/risks, like commodities, bonds, securities etc. Taking again into account the theory of portfolio choice, it is hence clear that 'since peripheral currencies are not as liquid as central ones (the same reasoning being valid for the assets denominated in each of these currencies), international agents will demand them only in the quest of high yields' (De Conti et al. 2013, p. 6).

The world faces therefore an 'international currency hierarchy' with important economic implications for the peripheral countries, but also for the international capital flows dynamics. Since the basic interest rates of some currencies are extremely different, international agents may execute profitable 'carry trade' operations. They may raise funds in central currencies, creating liabilities at relatively lower costs, and buy assets denominated in lower-ranked currencies, which offer higher returns. The operation of carry-trade makes pressure over the depreciation of the funding currency and the appreciation of the target one. As long as the expectations are sustained, there is over-appreciation of the target currencies. From a Minskyan perspective ${ }^{21}$, the reversal of the cycle determines a sudden 'flight from risk'

\footnotetext{
${ }^{19}$ This premium for the illiquidity of the currency at the international level is different from the country risk premium, since it does not concern domestic aspects, but rather the configuration of the IMS. Carneiro (2008) shows also that the interest rate in peripheral countries tend to be higher than in central ones due to the IMS hierarchy.

${ }^{20}$ Brazilian economic history is full of moments when the interest rate had to suddenly increase due to reasons that have no relation to the domestic economy. De Conti (2011) analyses data for countries that issue central currencies and peripheral currencies, concluding that the interest rate volatility tends to be higher in those that issue peripheral currencies.

${ }^{21}$ See Minsky (1986).
} 
and causes target currencies (usually the peripheral ones) to depreciate intensively. It is not difficult though to notice the transmission mechanism arising from the speculative and unstable character of liquidity cycles to the exchange rate movements in peripheral countries $^{22}$.

As mentioned above, from the international investor perspective, the portfolio composition is defined considering the variety of assets with their specific risk-return attributes. During the rise of the so-called 'appetite for the risk', there emerges a demand for increasingly less liquid assets in the search for exceptional yields. However, in the moment of reversion of the optimistic expectations, there is a sudden movement towards the most liquid assets. Since this portfolio reconfiguration is not national, but international; and it is not individual, but collective ${ }^{23}$, it determines international liquidity cycles ${ }^{24}$.

Such liquidity cycles have been object of intense investigation since the 2008 crisis, even within mainstream economics. Rey (2015), for instance, provides evidences on the functioning of international financial cycles. The author shows empirical correlation between the VIX index - which is widely seen as a market proxy for risk aversion and uncertainty - and international capital flows. She also finds that surges in gross flows are also accompanied by increases in leverage and in risky asset prices.

Ahmed and Zlate (2014) indicate that inflows directed to emerging economies are determined by global appetite for the risk, growth and interest rate differentials - assessing the predominant role of external factors. Accordingly, Bruno and Shin (2014) estimate that "global cost push" factors, such as VIX index and interest rate of central currencies, are more important to explain international financial cycles than "local demand pull" factors. Before them, within the Post-Keynesian tradition, Resende and Amado (2007) demonstrated through an empirical analysis that the economic cycles of three Latin American countries (Brazil, Argentina and Mexico) have been determined by the international financial system and not only by their respective domestic financial system. These researches have given empirical support to the theories of an "international currency hierarchy" 25 .

Within this tradition, Prates (2002) proposed the existence of three related asymmetries that affect peripheral countries. Firstly, the financial asymmetry implies that financial flows (inflows and outflows) in peripheral economies are usually important relatively to each country's financial market. Secondly, the monetary asymmetry determines that private capital flows are directed to peripheral economies mainly as long as there is a reduction in international liquidity preference and that assets allocated in peripheral countries are the first to be sold in moments of risk aversion and/or huge losses in other markets. Third and finally,

22 On recent empirical evidences of this correlation, see Bruno and Shin (2014). For a theoretical discussion, see De Conti et al. (2013).

${ }^{23}$ Due to conventions or even to "herd behavior".

${ }^{24}$ Prates (2002) also highlight that the international liquidity preference is determined by reasons that are external to the country where the assets are issued.

${ }^{25}$ Using a heterodox framework, Biancarelli (2007) had also analysed the international liquidity cycles of the end of the $X X^{\text {th }}$ and the beginning of the $X X I^{\text {st }}$ centuries, showing the alternation of massive movements of private capital flowing to or from peripheral countries. The author also shows that the direction of these flows is determined by reasons that are beyond the economic outcomes and the macroeconomic policies of peripheral countries. 
macroeconomic asymmetry, which is a result of the last two, consists in the lack of autonomy peripheral countries face to choose and implement national macroeconomic policies.

Concerning this last asymmetry, the necessity to set much higher interest rates as to compensate the lower liquidity of their domestic currencies is the first evidence, but not the only one, since the exchange rate policy is also under strict constraints.

As we have seen in the first section of this paper, MMT's allegation is that these constrains related to the level of the interest rates would actually be self-imposed, since the eventuality of a capital flight would not be a problem in a free floating exchange rate regime. The idea is that the exchange rate movements would automatically counteract these capital flights. Then, what MMT says is that a country that simply allows its exchange rate to freely float is able to autonomously choose the level of the interest rate. However, when we see the specificities of the exchange rate in peripheral countries, we see that this is not a smooth solution.

As a matter of fact, the free floating of exchange rate in peripheral countries leads to cyclical crisis because private capitals follow a speculative, volatile logic that finally has a huge impact over the volatility of exchange rates. Peripheral countries, thus, usually adopt some kind of administrated exchange rates with the purpose of avoiding both sudden default (caused by currencies mismatches of domestic agents) and inflationary pressures ${ }^{26}$. That means that macroeconomic policy should also be concerned with exchange rate stability objectives ${ }^{27}$.

Besides, international private capitals may impose strict market discipline over government budget, requiring full commitment with decreasing government deficits. If the government decides to abandon primary surpluses targets and increases its public deficits, the market will perceive it as a lower commitment to debt retirement and expect some depreciation trend over the exchange rate. Due to expectations, it may also imply higher longterm interest rates. Not much is needed to cause the 'flight to liquidity' movement, considering that financial investments in peripheral countries follow a speculative logic. Any action that goes against 'market discipline' and the so-called 'sound finance' may lead to selffulfilling prophecy of currency depreciation. Hence, MMT's proposal about the impossibility of default of a State when it is indebted in its own currency should take into account that the international demand for assets denominated in peripheral countries is so volatile that in the end the governments in peripheral countries feel strongly constrained by the permanent threat of a capital flight, inevitably incurring in a fiscal policy that is far from autonomous.

The macroeconomic autonomy is therefore more restricted in peripheral countries than in those that issue central currencies ${ }^{28}$. As argued, due to the IMS configuration, peripheral countries tend to have: i) higher interest rates in order to pay a premium for the

\footnotetext{
26 That is why even countries that officially declare a free floating exchange rate regime actually intervene in the forex market (having therefore a de facto dirty flotation regime).

${ }^{27}$ For details, see Carneiro (2008), De Conti (2011) and Prates (2015).

${ }^{28}$ Paula et al. (2017) presents an interesting discussion about the challenges peripheral countries face in order to implement economic policies in the age of financial globalization. According to them, peripheral countries should pursuit current account balance, "in order to prevent capital flows boom-bust-cycles with subsequent financial crises" (p. 17).
} 
illiquidity of their currencies at the international level; ii) volatile interest rates, since they reflect the 'international liquid preference' and it may suddenly change due to reasons that are exogenous to the country that is being analyzed; and iii) volatile exchange rates, due to the volatility of the capital that flows to peripheral countries ${ }^{29}$; iv) fiscal policy constraints arising from the country's insertion at the financial globalization (that is, the importance of the foreign capital for their financial markets).

It is therefore clear that international currency hierarchy states different degrees of freedom for the countries according to their position in the IMS.

Evidently, peripheral countries may face the above-mentioned trends. One important strategy that is adopted in many of them is the accumulation of huge international reserves, in order to increase the possibility of facing the reversion of the international liquidity cycles (and convince markets about this possibility). The second possible tool is erecting an apparatus of capital flow regulations that inhibit their speculative movements or reduce their effects over the exchange rate. Anyway, the task is not easy and the important point is that peripheral countries may not act as central ones, among other reasons, because their currency is not accepted as so at the international level.

\section{Final remarks}

The paper discussed the MMT, presenting its important refusal of the common views regarding the imprudence of public deficits. However, the paper also discussed some issues that are not consensual about the theoretical model MMT uses to support its audacious policy proposals. Moreover, there are also international political economy obstacles that would have to be offset.

When open economies are considered, there are further difficulties placed by international markets. A strong currency depreciation should be avoided if the country needs to obtain goods and services that are not available in domestic currencies, if it has debts denominated in the foreign currency, or if it wants to avoid inflationary pressures. Therefore, the country may need to attract foreign capitals by offering a minimum level of interest-rate (which, by the way, is exogenously set, by the international liquidity preference). Alternatively, it may adopt a fixed exchange rate, or issue its debt in the international currency. In all cases, domestic policy would have to follow other objectives than only full employment.

Furthermore, if there are several theoretical and political restrictions in applying the MMT in central countries, the obstacles placed to peripheral countries are even greater. Due to international monetary asymmetry, these countries are obliged to set their interest rate at a higher level to compensate the relative illiquidity of their domestic currencies. Moreover, 'sudden stops' could result from exogenous changes in liquidity cycles. Exchange rates, as a result, tend to be very volatile and should be subject to government administration.

In conclusion, this article proposes that in one hand MMT raises important questions about NMC's obsession for market friendly policies in central countries. Nevertheless, on the other hand, the MMT claim that countries are all sovereign to operate with their domestic

\footnotetext{
${ }^{29}$ In spite of this trend, some countries are successful in actively maintaining a stable exchange rate. The most eloquent example is China.
} 
currency - being capable of reaching full employment with price stability - is not observed in most countries, notably the peripheral ones. We propose therefore that a frank dialogue between authors that defend MMT and those who use a currency hierarchy framework may be very fruitful for the development of both theories and - most important - for the formulation of effective economic policies for peripheral countries.

\section{References}

Ahmed, S. and Zlate, A. (2014) "Capital flows to emerging market economies: a brave new world?", Journal of International Money and Finance, 48(Part B), p. 221-248.

Andrade, R. and Prates, D. (2013) "Exchange Rate Dynamics in a Peripheral Monetary Economy". Journal of Post Keynesian Economics, 35(3), p. 399-416.

Arestis, P. and Sawyer, M. (2008) "New consensus macroeconomics and inflation targeting: Keynesian critique." Economia E Sociedade, 17(special number), p. 629-653.

Biancarelli, A. (2007) Integração, ciclos e finanças domésticas: o Brasil na globalização financeira. PhD Thesis, Institute of Economics, University of Campinas.

Bielschowsky, R. (2000) Cinquenta anos de pensamento na CEPAL. Rio de Janeiro: Record/CEPAL.

Bruno, V. and Shin, H. (2014) "Cross-border banking and global liquidity". BIS working paper, n. 458, Bank for International Settlements.

Carneiro, R. (2008), "Globalização e inconversibilidade monetária". Revista de Economia Política, 28(4), p. 539-556.

Cesaratto, S. (2012a) "A reply to Wray - part I". Naked Keynesianism Blog. Available at <http://nakedkeynesianism.blogspot.com.br/2012/08/a-reply-to-wray-part-i.html>. Accessed on 15/07/2014.

Cesaratto, S. (2012b) "A reply to Wray - part II". Naked Keynesianism Blog. Available at <http://nakedkeynesianism.blogspot.com.br/2012/08/a-reply-to-wray-part-ii.html>. Accessed on 15/07/2014.

Cesaratto, S. (2012c) "The spurious victory of MMT". Naked Keynesianism Blog. Available at <http://nakedkeynesianism.blogspot.com.br/2012/07/spurious-victory-of-mmt.html>. Accessed on 15/07/2014.

Cesaratto, S. (2016) "The state spends first: Logic, facts, fictions, open questions", Journal of Post Keynesian Economics, 39(1), p. 44-71.

Cohen, B. (1998) The geography of money. Ithaca: Cornell University Press.

De Conti, B. (2011) Políticas cambial e monetária: os dilemas enfrentados por países emissores de moedas periféricas. Phd Thesis, University of Campinas and University of Paris 13.

De Conti, B. and Prates, D. (2016) "The International Monetary System hierarchy: determinants and current configuration". The 28th Annual EAEPE Conference, Manchester, UK.

De Conti, B., Prates, D. and Plihon, D. (2014) “A hierarquia monetária e suas implicações para as taxas de câmbio e de juros e a política econômica dos países periféricos". Economia e Sociedade, 23(2), p. 341-372. 
Eichengreen, B., Hausmann, R. and Panizza, U. (2005) "The Mystery of Original Sin". In: B. Eichengreen and R. Hausmann (eds.) Other People's Money. Chicago and London: Chicago University Press.

Flassbeck, H. (2001) "The exchange rate: economic policy tool or market price?" Discussion paper, n. 157, United Nations Conference on Trade and Development, Geneva.

Friedman, M. (1953) "The case for flexible exchange rates", In: M. Friedman (ed.) Essays in Positive Economics, Chicago: University of Chicago Press, pp. 157-203.

Goodhart, C. (1989) Money, Information and Uncertainty. Cambridge, MA: The MIT Press.

Guttmann, R. (2016) Finance-Led Capitalism. New York: Palgrave Macmillan US.

Guttmann, R. and Plihon, D. (2011) "Whither the Euro? History and Crisis of Europe's SingleCurrency Project", In: G. Epstein and H. Wolfson (eds.) Handbook of the political economy of financial crises, New York: Oxford University Press, pp.357-377.

Keynes, J. (1930 [1970]) "Treatise on money, vol.2 - The Applied Theory of Money", in The Collected Writtings of John Maynard Keynes, vol. VI. London: MacMillan.

Keynes, J. (1936 [1964]) The general theory of employment, interest and money. London: MacMillan. 14ed.

Knapp, G. (1924) The State Theory of Money. London: Macmillan \& Company Limited.

Krugman, P. and Taylor, L. (1978), "Contractionary Effects of Devaluation," Journal of International Economics, 8(3), pp. 445-456.

Lavoie, M. (2013) "The monetary and fiscal nexus of neo-chartalism: a friendly critique". Journal of Economic Issues, 47(1), p. 1-32.

Lavoie, M. (2014) Post-Keynesian economics: new foundations. Cheltenham: Edward Elgar Publishing.

Lerner, A. (1943) "Functional Finance and the Federal Debt". Social Research, 10(1), p. 38-51.

Minsky, H. (1986) Stabilizing an Unstable Economy. London: McGraw-Hill Education.

Mitchell, W. (1998) "The Buffer Stock Employment Model and the NAIRU: The Path to Full Employment", Journal of Economic Issues, 32(2), p. 547-555.

Mitchell, W. and Wray, R. (2005) "In defense of employer of last resort: a response to Malcolm Sawyer", Journal of Economic Issues, 39(1), p. 235-244.

Palley, T. (2013) "Money, fiscal policy, and interest rates: a critique of modern monetary theory", Working Paper, n. 109, Institute for Macroeconomics, Dusseldorf, Germany.

Palley, T. (2015a) "Money, Fiscal Policy, and Interest Rates: a critique of modern monetary theory", Review of Political Economy, 27(1), p. 1-23.

Palley, T. (2015b) "The Critics of Modern Money Theory (MMT) are Right.' Review of Political Economy, 27(1), p.45-61.

Paula, L., Fritz, B. and Prates, D. (2017) "Keynes at the periphery: Currency hierarchy and challenges for economic policy in emerging economies", Journal of Post Keynesian Economics, 40(2), p. 183-202.

Prates, D. (2002), Crises financeiras dos países "emergentes": uma interpretação heterodoxa. PhD Thesis, Institute of Economics, University of Campinas. 
Prates, D. (2015) O regime de câmbio flutuante no Brasil 1999-2012: especificidades e dilemas. Brasília: IPEA.

Resende, M. (2005) O padrão dos ciclos de crescimento da economia brasileira: 19472003. Economia e sociedade, Campinas, 14(1-24), p.25-55.

Resende, M. and Amado, A. (2007) Liquidez internacional e ciclo reflexo: algumas observações para a América Latina. Revista de Economia Política, 27(1), p.41-59.

Rey, H. (2015) "Dilemma Not Trilemma: The Global Financial Cycle and Monetary Policy Independence" Working Paper, n. 21162, National Bureau of Economic Research, Cambridge.

Rochon, L. and Vernengo, M. (2003) "State money and the real world: or Chartalism and its discontents", Journal of Post Keynesian Economics, 26(1), p. 57- 67.

Tcherneva, P. (2006) "Chartalism and the tax-driven approach", in P. Arestis and M. Sawyer (eds.), A Handbook of Alternative Monetary Economics, Cheltenham: Edward Elgar, p. 69-86.

Thirlwall, A. (1979) "The balance of payments constraint as an explanation of the international growth rate differences." BNL Quarterly Review, 32(128), p.45-53.

Tymoigne, E. and Wray, R. (2014) "Modern money theory: a reply to Palley", Review of Political Economy, 27(1), p. 24-44.

Wray, R. (1998) Understanding Modern Money: The Key to Full Employment and Price Stability, Cheltenham, U.K: Edward Elgar.

Wray, R. (2007) "The Employer of Last Resort Programme: Could It Work for Developing Countries?", Economic and Labour Market Paper, no. 2007/5, International Labour Office, Geneve, Switzerland.

Wray, R. (2012) "Paul McCulley - MMT Won: Declare Victory But Be Magnanimous About It". EconoMonitor, Randall Wray Blog. Available at $<$ http://www.economonitor.com/Irwray/2012/06/25/paul-mcculley-mmt-wondeclare-victory-but-be-magnanimous-about-it/>. Accessed on 24/03/2016.

Wray, R. (2014a) "MMT and external constraints". EconoMonitor, Randall Wray Blog. Available at $\quad$ http://www.economonitor.com/Irwray/2014/02/24/mmt-and-externalconstraints/>. Accessed on 24/03/2016.

Wray, R. (2014b) "From the State Theory of Money to Modern Money Theory: An Alternative to Economic Orthodoxy", The Levy Economics Institute Working Paper Collection, n.792, p. 1-35. 